\title{
Prototype Design of Body Mass Index Measurement for Adolescence to Prevent Chronic Energy Deficiency in Pregnancy Based on Arduino
}

\author{
Alinea Dwi Elisanti* \\ Clinical Nutrition Program Study, \\ Health Departement \\ Politeknik Negeri Jember \\ Jember, Indonesia \\ alinea@polije.ac.id \\ ORCID: 0000-0003-1270-6281
}

\author{
Ratih Ayuninghemi \\ Technical Information Study Program \\ Information Technology Departement \\ Politeknik Negeri Jember \\ Jember, Indonesia \\ ratihayuninghemi@polije.ac.id
}

\author{
Efri Tri Ardianto \\ Medical Record of Program Study \\ Health Departement \\ Politeknik Negeri Jember \\ Jember, Indonesia \\ efritriardianto@polije.ac.id \\ ORCID: 0000-0001-7580-6832
}

\begin{abstract}
Chronic Energy Deficiency (CED) in pregnant women is just becoming a nutrition issue during the perinatal period in Indonesia. CED occurs when energy and protein necessity, are not fulfilled by the intake consumed. CED during pregnancy has a major impact on complications for mothers, babies and perinatal mortality. CED in pregnancy is a continuation of CED in adolescence. CED screening in adolescence measuring using Body Mass Index (BMI). BMI is actually more accurate to identify the real condition of nutritional status at the time of measurement but, it unusually done because the process is more complicated, the cadres or midwives have to calculate manually. However, It is compulsory to design a simpler and practical BMI measuring instrument. This research aim to create prototype design of BMI for adolescence to prevent CED in pregnancy using an arduino. In order to help the Public Health Center (PHC) for examination CED before pregnancy. This research design utilizes a system development life cycle (SDLC), which the stages of planning, analysis, design, implementation, testing and management applied to system. The prototype design starts with planning the tools, the calibration process, the detection of the sensor, the BMI calculation consist of 4 categories (CED, normal, overweight, and obese) for Indonesian female. This categories will appear on the LCD display. This prototype can be developed into an android application, so it was very useful for adolescence and women in PHC or Integrated Post Service in Indonesia.
\end{abstract}

Keywords-adolescence, Arduino, body mass index, chronic energy deficiency, pregnancy, prototype

\section{INTRODUCTION}

Nutritional status is an important aspect for pregnant women to get through their pregnancy well. Pregnant women must have a normal nutritional status. Nutritional problems during pregnancy trigger complications in pregnancy. These complications will give a serious impact on the well-being of the mother and the fetus in the womb. One of the nutritional problems of pregnant women is chronic energy deficiency (CED). CED is a nutritional problem caused by a lack of food intake for a long time, especially energy intake from macronutrients (carbohydrates, protein, and fat) and micronutrients, especially vitamin A, vitamin $\mathrm{D}$, folic acid, iron, zinc, calcium, and iodine [1].
Deficiency of micronutrients since a woman is of childbearing age on an ongoing basis (adolescence to pregnancy) has an impact on CED during pregnancy. The highest prevalence of risk of CED in women of childbearing age is experienced by adolescents aged 15-19 years, reaching $36.3 \%$ [2]. CED in pregnancy begins with the incidence of CED risk identified by measuring the mid- circumferenceupper arm (MCUA). The prevalence of CED risk in pregnant women (15-49 years) is still quite high, namely $24.2 \%$. The basis for determining the percentage of CED pregnant women refers to the 2013 Riskesdas results [3]. It is expected that the percentage of pregnant women in CED will decrease every year. This CED outcome indicator uses the proportion of pregnant women whose MCUA is measured using the MCUA band with a measurement of less than $23.5 \mathrm{~cm}$.

Monitoring nutritional status shows the percentage of pregnant women at risk of CED reaches $14.8 \%$ [4]. A part from nutritional factors, it is known that there are several social factors that influence the incidence of CED. [5] parity, number of family members, family income, and socioeconomic factors influence the incidence of CED in pregnant women. The CED impact on pregnant women and the fetus can be quite complex, pregnant women in CED are at risk of experiencing a decrease in muscle strength during the delivery process resulting in fetal death, birth defects, low birth weight babies (LBW), and even infant mortality, CED pregnant women can interfere with fetal growth, brain and metabolism are at risk of causing non-communicable diseases in adulthood [6]. CED during pregnancy triggers premature birth, which affects physical growth (stunting) [2]. [7] CED also affects the incidence of anemia in pregnant women.

The key to finding CED and malnutrition during pregnancy lies in the initial screening performed. CED examination in pregnancy at the Public Health center (PHC) is usually done by measuring the mid-circumference-upper arm (MCUA) and rarely using a Body Mass Index (BMI) measurement. However, there is a relationship between BMI and MCUA in the first trimester of pregnant women [8] BMI is the anthropometric index most widely used in epidemiological studies as well as in clinical practice to classify a person's weight status [6]. BMI in the mother before 
pregnancy is a benchmark for weight gain during pregnancy. This increase in body weight affects the delivery process and the weight of the baby born, whether it is normal weight, macrosomia or low birth weight [9]. BMI measurement is actually more accurate to know the real condition of nutritional status at the time of measurement. However, BMI measurement is still not a custom in screening at PHC and Integrated Service Post (ISP) because the process is more complicated, cadres or midwives have to calculate manually. So creating screening tools for a women before pregnant was important to do, so the women of childbearing age need to maintain a normal BMI before marriage.

\section{RESEARCH METHOD}

This study resolves to design a BMI measurement system for adolescent based on an Arduino. This research design utilizes a system development life cycle (SDLC), includes the stages of planning, analysis, design, implementation, testing, and management applied to system design. However, this study did not apply the SDLC method completely. This research finish at design stages. Before taking the planning stage, we had taken preliminary studies for about 6 months. We have an experience from Integrated Post Service (IPS) at a different location at Jember district, we found that there is no early screening to detect CED in an adolescent.

Apart from the limitations of anthropometric measurement tools, it is also because the measurement of BMI in adolescents takes a long time because it goes through several processes that are done manually. Then we take some literature study form previous research, so we decided to compile a prototype uses BMI limits for an Indonesians with female sex according to the Indonesian Ministry of Health, 2003. Using 4 main criteria, namely CED with BMI $<17 \mathrm{~kg} /$ $\mathrm{m} 2$, Normal with BMI $17-23 \mathrm{~kg} / \mathrm{m} 2$, Overweight with BMI $>23-27 \mathrm{~kg} / \mathrm{m} 2$ and Obesity with BMI > $27 \mathrm{~kg} / \mathrm{m} 2$ [10].

This prototype design was carried out in the robotics laboratory of the Politeknik Negeri Jember. The trial was conduct four times, involving lecturers and students from the health department, two robotics laboratory technicians, and a lecturer majoring in information systems.

\section{RESUlt AND DisCUSSION}

This study produced a prototype of an anthropometric detection system for nutritional status for adolescent (women before pregnant), using the parameters for calculating body mass index [11]. Body Mass Index (BMI) is a measuring tool used to determine a person's nutritional status related to underweight or overweight. The nutritional status of adolescents was measured using BMI using parameters of body weight and height [12]. The planning process is carried out based on the obstacles found during field observations, namely at the PHC and ISP. The problem analysis was carried out based on the researcher's experience while working in the hospital, so that there were several weaknesses in measuring body mass index, especially in women of reproductive age before pregnancy. The prototype design was carried out with the two assistance of robotics laboratory at the Politeknik Negeri Jember, who had previously been given explanations and discussions with researchers. Creating this protoype is considered very important to reduce the workload of health workers and cadres in detecting CED before pregnancy. In addition, this prototype was designed to reduce the high incidence of human error when measuring nutritional status at IPC and PHC. Adolescent and pregnant women are the object of data input, while the data input includes body weight and height, then the data is read by the height and weight sensors.

The results of the prototype design are described in the form of a flowchart as in Figure 1. The flow of the system design starts from the load cell sensor calibration process and the HC-SR 04, followed by reading the load cell sensor and the HC-SR 04 sensor. If the sensor is read then proceed to the detection of the weight sensor and height sensor. This research uses the HC-SR 04 sensor. However, if the sensor is not readable then the process of reading the load cell sensor and the HC-SR 04 sensor is repeated again. The next stage is the BMI calculation which is processed through the Arduino system, the calculation results will be displayed on the LCD screen and the health worker can note this measurement result in a cohort book.

The similar studies have been carried out by many previous researchers, there are many studies on BMI-related applications. For example, a study entitled automatic body selection gate on arduino-based playing, which uses utilizing the HC-SR04 ultrasonic sensor as a height measurement and processed using Arduino [13]. Another research conducted by Bin Dai; Rung-Ching Chen; Wei-Bin Yang that presents an application that using Arduino and Bluetooth electronic scale to connect to smart phones to obtain weight information of daily water intake. Bluetooth technology is low-power, it can ensure the reliability of data transmission using an Arduino board as major application development tools [14]

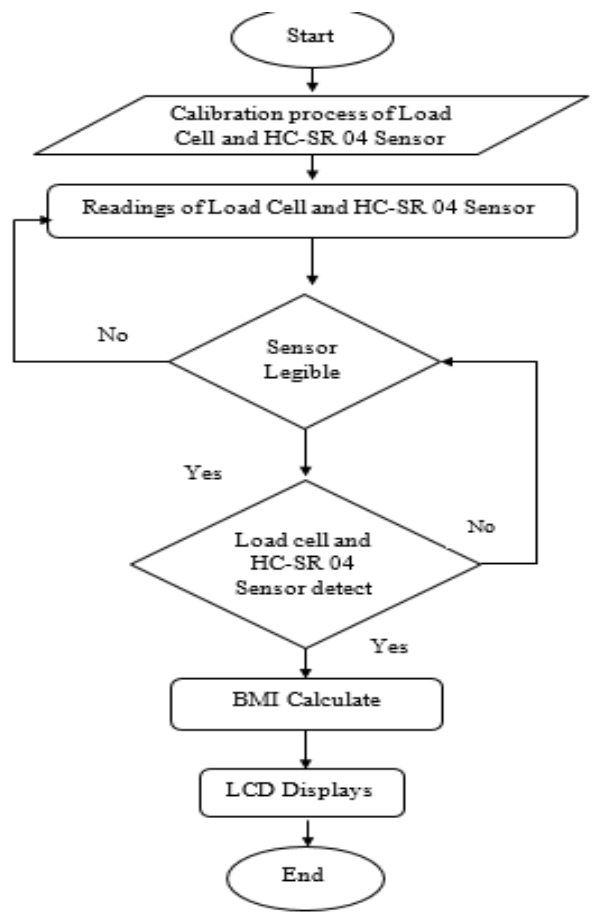

Fig. 1. Flowchart Prototype design of BMI For Adolescence

While this prototype block diagram is depicted as in Figure 2.

The similar research was conducted by Bernard Mark S. Baladad et al, who calculate the weight and height measurement and display its BMI measurement automatically upon entering in the system jamb and save the BMI 
measurement in the system's database. The proponents designed a circuit that combined the functions of the ultrasonic proximity sensor and weight sensor in one system and developed software embedded in two microcontrollers which control and manipulate the whole system of the design project. The design utilized the hardware tools which include ultrasonic proximity sensor, weight sensor, Gizduino ATMEGA328 and sensor Amplifier [15].

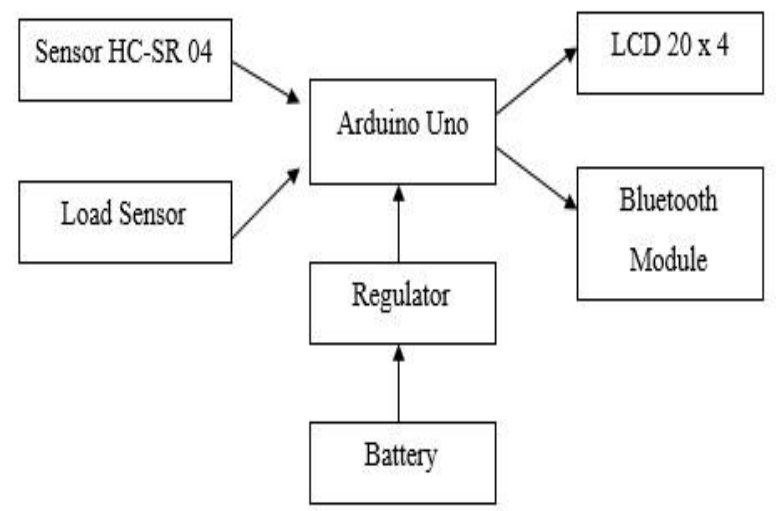

Fig. 2. Block Diagram of BMI For Adolescence

Digitally height and weight of human body measuring instrument based sound module arduino is a modern measuring instrument that serves to measure the height and weight of the human body and provides information on BMI (body mass index) and weight of the human body. This tool is designed using ultrasonic sensors SRF-04 as a measurement of height and Load Cell as a measurement of weight and has an LCD display and output ofthe sound module. This tool has a maximum height limit measure measuring $200 \mathrm{~cm}$ and maximum weight limit of $200 \mathrm{Kg}$. From the results of testing this tool has a fault or error in the measurement of the weight of $0,43 \%$. And measurement error or error in height measurement of $0,72 \%$ [16]

Design and development of automatic height measuring devices using ultrasonic sensor HC-SR04 based on arduino R3 by Sembiring and Mesa (2019) [17]. The difference between the objectives of this study and previous studies is the type of sensor used and the specific BMI classification parameters for Indonesian female.

The distinguishes of this study is the parameters for determining BMI are based on BMI guidelines for women released by the Ministry of Health of the Republic of Indonesia. BMI for Indonesians, especially for women before preparing for pregnancy. It will develop to the lower error in BMI measurement from the previous research.

\section{CONCLUSION}

CED in pregnancy can occur due to CED in adolescence, especially in young women. Prevention of CED in adolescent girls can be done through BMI screening and nutrition education in adolescents. However, measurement of BMI in adolescents is very rarely carried out because of the long process and long time, while health services at the ISP are time-limited and only specifically for toddlers. So we need an anthropometric tool that is designed according to the needs of the community. The Prototype design of BMI measurement can be developed into an android application, will make it easier to screen BMI in adolescents because it will be design with a lower error in the measurement process. So, it was very useful for health worker, adolescence and women in Indonesia to take BMI measurements independently.

\section{ACKNOWLEDGMENT}

The authors are grateful to the Ministry of Education and Culture of The Republic of Indonesia for PNBP research funding with contract number 416 / PL17.4 / PG/ 2020.

\section{REFERENCES}

[1] Kementerian Kesehatan RI, "Directorate General of Public Health Performance Report 2016 - Penelusuran Google.”.

[2] Kementerian Kesehatan RI, "Basic Health Research 2018," Kementerian Kesehatan, 2018.

[3] Kementerian Kesehatan RI, "Basic Health Research 2013,” 2013.

[4] Kementerian Kesehatan RI, "Pocket book of Nutritional Status Monitoring Results (SMR) 2017 - Sehat Negeriku,”Jan 2017.

[5] Y. Anggraini, J. Kebidanan, and P. Kemenkes Tanjungkarang, "The Effect of Demography And Socioeconomics on The Events of Chronic Energy Deficiency of Pregnant Women In Metro City, Lampung Province,” Jan. 2016. doi: 10.26630/JK.V4I2.84.

[6] R. Rosário et al., "Body Mass Index Categories and Attained Height in Portuguese Adults," Obes. Facts, vol. 11, no. 4, pp. 287-293, Sep. 2018, doi: 10.1159/000491754.

[7] F. Aminin, A. Wulandari, R. P. Lestari, J. Kebidanan, and P. Kemenkes Tanjungpinang, "The Effect Of Chronic Energy Deficiency (Ced) With The Event Of Anemia In Pregnant Women," Jan. 2016. doi: 10.26630/JK.V5I2.52.

[8] A. R. Muslimah and R. W. Hidayati, "Relationship Of Body Mass Index With Mid Circumferencia Upper-Arm (MCUA) Of Trimester I Pregnant Woman At Puskesmas Umbulharjo I, Yogyakarta City 2016 Year," Nov. 2017.

[9] E. Ota et al., "Indice maternel de masse corporelle et augmentation du poids en gestation et leur association avec les observations périnatales au Viet Nam,” Bull. World Health Organ., vol. 89, no. 2, pp. 127-136, Feb. 2011, doi: 10.2471/BLT.10.077982.

[10] Depkes RI, Practical Guidelines for Medical Nutritional Therapy . 2003.

[11] Depkes RI, Practical Guidelines for Medical Nutritional Therapy . 2004.

[12] Supariasa, Assessment of Nutritional Status. Jakarta: Penerbit Buku Kedokteran EGC., 2013.

[13] B. Ramadhan, "Automatic Height Selection Gate on Arduino-based Playgrounds," 2016.

[14] R. C. and W. Y. B. Dai, “Using Arduino to Develop a Bluetooth Electronic Scale for Water Intake," Int. Symp. Comput. Consum. Control (IS3C), Xi'an, 2016, pp. 751-754, 2016, doi: 10.1109/IS3C.2016.192.

[15] B. M. S. Baladad, J. V. Magsombol, J. N. B. Roxas, E. L. De Castro, and J. A. Dolot, "Development of automated body mass index calculation device," Int. J. Appl. Eng. Res., vol. 11, no. 7, pp. 51955201, 2016.

[16] M. Kusriyanto and A. Saputra, "Design of Integrated Digital Scales BMI Information with Sound Output Based on Arduino Mega 2560," Teknoin, vol. 22, no. 4, pp. 269-275, 2016, doi: 10.20885/teknoin.vol22.iss4.art4.

[17] T. M. Sembiring, "Design And Development Of Automatic Height Measuring Devices Using Ultrasonic Sensor Hc - Sr04 Based On Arduino R3," Jan. 2019. 